\title{
De tijden veranderen - nu wij nog ...
}

Citation for published version (APA):

Faber, C. G. (2015). De tijden veranderen - nu wij nog .... Maastricht University. https://doi.org/10.26481/spe.20150605kf

Document status and date:

Published: 05/06/2015

DOI:

$10.26481 /$ spe.20150605kf

Document Version:

Publisher's PDF, also known as Version of record

\section{Please check the document version of this publication:}

- A submitted manuscript is the version of the article upon submission and before peer-review. There can be important differences between the submitted version and the official published version of record.

People interested in the research are advised to contact the author for the final version of the publication, or visit the DOI to the publisher's website.

- The final author version and the galley proof are versions of the publication after peer review.

- The final published version features the final layout of the paper including the volume, issue and page numbers.

Link to publication

\footnotetext{
General rights rights.

- You may freely distribute the URL identifying the publication in the public portal. please follow below link for the End User Agreement:

www.umlib.nl/taverne-license

Take down policy

If you believe that this document breaches copyright please contact us at:

repository@maastrichtuniversity.nl

providing details and we will investigate your claim.
}

Copyright and moral rights for the publications made accessible in the public portal are retained by the authors and/or other copyright owners and it is a condition of accessing publications that users recognise and abide by the legal requirements associated with these

- Users may download and print one copy of any publication from the public portal for the purpose of private study or research.

- You may not further distribute the material or use it for any profit-making activity or commercial gain

If the publication is distributed under the terms of Article $25 \mathrm{fa}$ of the Dutch Copyright Act, indicated by the "Taverne" license above, 
Prof. dr. Catharina (Karin) G. Faber

Faculty of Health, Medicine and Life Sciences

\section{De tijden veranderen - nu wij nog....}


Rede

Prof.dr. Catharina (Karin) G. Faber

Faculty of Health, Medicine and Life Sciences

De tijden veranderen -

nu wij nog.... 
All rights reserved. No part o this publication may be reproduced, modified, stored in a retrieval system or made public without the prior written permission of the author or publisher. 
De tijden veranderen -

nu wij nog....

\section{Rede}

Uitgesproken bij de aanvaarding van het ambt van bijzonder Hoogleraar

Neuromusculaire aandoeningen aan de Faculteit Health, Medicine and Life Sciences

Maastricht, 5 juni 2015

Door prof.dr. Catharina (Karin) G. Faber 
Geachte decaan, vice-decaan, leden van de begeleidingscommissie, leden van de Raad van Bestuur van het Maastricht UMC+, collega's, patiënten, familie en vrienden

Met deze rede met als titel: 'De tijden veranderen, nu wij nog....' wordt een mijlpaal gemarkeerd.

Mijn leeropdracht betreft 'Neuromusculaire aandoeningen', en het instellen van deze leerstoel geeft binnen het Maastricht UMC+ een gezicht aan deze groep ziekten.

Vandaag vertel ik $\mathrm{u}$ meer over de inhoud, de doelstellingen en de waarde van hetgeen wij doen, en over de richting die we op moeten. Dit zijn alle redenen om iets te doen. Het is echter niet het waarom.

Mijn eerste waarom zit hier recht voor mij: Thomas, David en Casper. Zij zijn het die mij steeds opnieuw leren te kijken naar wat we doen en hoe we het doen. Zij zijn onbevangen en kritisch. Vanuit hun visie leer ik steeds opnieuw en vanuit een andere invalshoek naar dingen te kijken, en realiseer ik me dat we doorlopend moeten veranderen en aanpassen. Zij doen niet anders, en ze doen dat met het grootste gemak.

Toen het bericht kwam dat ik was benoemd tot hoogleraar, kwam Thomas aan de keukentafel bij mij zitten, zijn telefoon in de hand. Hij vuurde allerlei vragen op me af, en alles werd genoteerd, met razende snelheid, in de telefoon.

Als wij buiten lopen en ons afvragen of het misschien gaat regenen, kijken wij, als veertigers en vijftigers naar de lucht boven ons. Kinderen niet. Zelfs als zij een druppel voelen, pakken zij hun telefoon om in te schatten of er een bui komt of niet... hoe lang dat duurt, en hoe hevig het zal zijn. Als ik David bezig zie, met vrienden, op X-box of computer, koptelefoon op, onder luid gejoel, dan kan ik op het scherm nauwelijks volgen wat er gebeurt, zo snel gaat het. Ik zie Casper muziek maken via de iPad, en zijn vingers schieten zo vlug over het scherm, dat ik ervan duizel. En hoewel mijn kinderen voor mij zeer uitzonderlijk zijn, is dit binnen hun groep leeftijdsgenoten geen bijzonderheid. Zij groeien op in een andere tijd dan ik dat deed, leren andere vaardigheden, en daarmee ontwikkelen hun hersenen zich op een andere manier dan die van kinderen 50 jaar geleden. Het een ontwikkeling die we niet tegen kunnen houden, en die kinderen ook vaardigheden bijbrengt die ze in deze tijd nodig hebben. Het gemak waarmee zij omgaan met deze ontwikkelingen, en omgaan met veranderingen, is bewonderenswaardig, en daarvan kunnen wij veel leren.

In feite zouden we wat meer kind moeten blijven. Verandering is noodzakelijk, zonder verandering is er geen verbetering mogelijk. Ik zal $u$ dit vandaag laten zien. 
Mensen, en vooral wij volwassenen, hebben vaak de neiging in verzet te komen tegen veranderingen, het lijkt of wij het kind-zijn kwijt zijn geraakt. Terwijl we juist doorlopend zouden moeten willen veranderen om te verbeteren. Hierbij is dus het kind in ons heel belangrijk. En we moeten de dingen met passie doen: wanneer we geloven in wat we doen, en geloven in waarom we dat doen, dan is alles mogelijk.

Lieve Thomas, David en Casper: jullie zijn mijn eerste 'waarom' en dit is dus voor jullie. Wat ik heb geleerd, en wat ik graag wil dat jullie onthouden, is dat je alles kunt bereiken, als je er maar in gelooft. Als je gelooft in wat je doet, heb je passie en drive, en dat betekent dat je anderen mee kunt nemen op je weg. Dan is geen berg te hoog, en geen weg te lang. Dan zal het zijn zoals al op de geboortekaart van David stond: 'op de weg die ik ga, zal ik op een dag stilstaan, verbaasd te zien hoe ver ik ben gekomen'...

Mijn tweede 'waarom' zijn de patiënten, in ons geval patiënten met een neuromusculaire aandoening, een spierziekte. Voor hen doen wij wat we doen, om hen draait het. En ook van hen leer ik ieder dag opnieuw. Neuromusculaire aandoeningen zijn aandoeningen van de zenuwen, overgang van zenuw naar spier of van de spieren zelf, maar naast de spieren kunnen ook andere weefsels of organen zijn aangedaan. Daarbij gaat het vaak om erfelijke aandoeningen, maar ook om bijvoorbeeld ontstekingsachtige aandoeningen. Veel van deze ziekten zijn relatief zeldzame ziekten, zogenaamde weesziekten of orphan diseases Maar al die zeldzame ziekten samen zijn niet zo zeldzaam.

Omdat het om ziektes gaat die zeldzaam zijn, hebben in Nederland de verschillende neuromusculaire centra een samenwerkingsverband gesloten in het Spierziekten Centrum Nederland. Het Spierziekten Centrum Nederland werkt nauw samen met de patiëntenvereniging Spierziekten Nederland en met het Prinses Beatrix Spierfonds. Op deze manier wordt ook gewaarborgd dat de stem van de patiënt wordt gehoord. Per slot van rekening is de patiënt degene waarom het te doen is. En de patiënt hoort het waarom van ons allemaal te zijn.

Het Spierziekten Centrum Maastricht UMC+ maakt deel uit van dit landelijk Spierziekten Centrum Nederland. Hierbij heeft ieder spierziekten centrum van de verschillende UMC's zijn eigen aandachtsgebieden. De aandachtsgebieden van het Spierziekten Centrum Maastricht zijn myotone dystrofie en dunnevezelneuropathie. Daarnaast speelt klinimetrie een belangrijke rol, dit is het meten van de klinische en functionele situatie van de patiënt. Ik zal u achtereenvolgens meenemen naar deze deelgebieden. 


\section{Myotone dystrofie}

Myotone dystrofie is de meest voorkomende erfelijke spierziekte op volwassen leeftijd. Het is ook één van de meest complexe aandoeningen: de ziekte kan op elke leeftijd beginnen, en er kunnen vele verschillende organen of weefsels zijn aangedaan.

Een opvallend verschijnsel bij myotone dystrofie is anticipatie, wat betekent dat de ziekteverschijnselen binnen één familie per generatie eerder beginnen en zich ernstiger uiten. Dit werd beschreven door mijn voorganger Chris Höweler.

Myotone dystrofie wordt veroorzaakt door een abnormale verlenging van een deel van het DNA. Op het gen voor myotone dystrofie komt in een normale situatie een bepaalde herhaling voor, namelijk een CTG-herhaling. Deze CTG-herhaling varieert van 5 tot 37. Bij patiënten met myotone dystrofie is dit aantal toegenomen van 50 tot 3000 of zelfs hoger. De lengte van de herhaling neemt toe bij opeenvolgende generaties, wat het fenomeen anticipatie verklaart. Op basis van de beginleeftijd en de ziekteverschijnselen kunnen vier vormen worden onderscheiden: het milde type, het volwassen of klassieke type, het kindertype en de aangeboren vorm.

De spierklachten bestaan uit myotonie, dit is het vertraagd ontspannen van spieren, en spierdystrofie, het dunner en zwakker worden van de spieren. Er ontstaat zwakte van de armen en benen, en ook van het gelaat. Hierdoor ontstaat vaak een kenmerkend gezicht, met ingevallen slapen en wangen en afhangende oogleden. Dit beïnvloedt de mimiek, wat vaak gevolgen heeft voor de manier waarop patiënten met myotone dystrofie door hun omgeving worden benaderd. Door zwakte van de mond- en keelspieren kan het spreken onduidelijk worden, wat gevolgen heeft voor de communicatie.

Vele andere orgaansystemen en weefsels kunnen betrokken raken, zoals de hersenen, het hart, de darmen, de longen en de ogen.

Betrokkenheid van de hersenen leidt tot vermoeidheid, toegenomen slaapbehoefte en een vermindering van initiatief (een zogenaamde stoornis in de uitvoerende functies), en dit leidt tot ernstige beperkingen in het dagelijks leven, bij werk en bij school. Het herkennen van deze symptomen is belangrijk om de beperkingen in het dagelijks en sociaal functioneren van patiënten met myotone dystrofie te begrijpen en patiënt en zijn omgeving goede uitleg te kunnen geven.

Betrokkenheid van het hart is één van de belangrijkste factoren voor de prognose van patiënten, Mieke Hermans heeft dit de afgelopen jaren onderzocht. Een derde van de patiënten overlijdt aan problemen van het hart, vaak plotseling. Het geleidingssysteem, de bedrading, van het hart, is vooral aangedaan, en kan aanleiding geven tot een zeer trage hartslag. In dat geval kan een pacemaker nodig zijn. Bij een verhoogd risico op hartritmestoornissen kan een implanteerbare defibrillator (ICD) worden geplaatst om acute hartdood te voorkomen

Klachten van het maagdarmstelsel komen veel voor. Doordat zowel dwarsgestreepte als gladde spieren aangedaan zijn, kan het gehele maagdarmstelsel betrokken zijn, 
wat kan leiden tot slikklachten, stilstand van voedsel in de maag, galstenen, diarree, obstipatie en incontinentie voor ontlasting.

Spierzwakte en verminderde prikkels vanuit de hersenen kunnen leiden tot hypoventilatie, een verminderde gasuitwisseling in de longen, vooral 's nachts, wat klachten kan geven van ochtendhoofdpijn en slaperigheid overdag. Nachtelijke beademing met een neuskapje kan dan nodig zijn.

Herhaaldelijke longontsteking kan het gevolg zijn van verslikken in voedsel, drinken of speeksel. Longontsteking kan leiden tot ernstige ademhalingsproblemen en is de oorzaak van overlijden bij een derde van de patiënten.

Na deze opsomming is $u$ duidelijk dat dit een ernstige en complexe ziekte is, en dat patiënten bij vele verschillende artsen komen. Daardoor heeft soms niemand overzicht over wat er gebeurt, en wat er zou moeten gebeuren. Dit is de reden dat er in afgelopen jaren door ons een landelijke multidisciplinaire richtlijn is ontwikkeld, waarin onder andere is aangegeven dat er één coördinator moet zijn voor een patiënt met myotone dystrofie.

Initiatiefarmoede zorgt er voor dat patiënten vaak onvoldoende zorg krijgen, doordat ze bijvoorbeeld afspraken vergeten of onvoldoende acht slaan op bepaalde klachten of symptomen. Dit betekent dat wij de zorg voor deze patiënten anders moeten inrichten en organiseren dan voor veel andere patiënten. Wij moeten dus ons systeem of proces aanpassen aan de patiënten. Waar in de gezondheidszorg in het algemeen wordt gezegd dat de patiënt de regie moet voeren over zijn of haar behandeling, zou dat voor deze patiënten in het algemeen zeer slecht uitpakken. Zij zijn juist gebaat bij actieve bemoeienis van de zorgverlener, en een coördinator is een absolute noodzaak.

Om deze multidisciplinaire en actieve zorg landelijk te kunnen vormgeven, en daarmee de zorg voor patiënten met myotone dystrofie te verbeteren, hebben het Maastricht UMC+ en het Radboud UMC de handen ineen geslagen. Samen vormen zij het myotone dystrofie centrum Nederland, en de bedoeling is zowel voor patiënten als voor andere hulpverleners de herkenbaarheid van myotone dystrofie en de zorg voor patiënten met myotone dystrofie te verbeteren.

Meerdere vragen liggen nog open. Welke factoren bepalen hoe snel iemand achteruit gaat, en kunnen we daar iets aan doen? Zijn er bepaalde risicofactoren voor het ontwikkelen van ernstige hartproblemen? Hoe kunnen we de nachtelijke ademhalingsproblemen het beste behandelen? Welke rol kan een multidisciplinair team spelen in het geheel spelen?

In de afgelopen jaren is veel onderzoek gedaan naar de ontwikkeling van een behandeling voor myotone dystrofie. De huidige behandeling bij myotone dystrofie is gericht op het bestrijden van symptomen of klachten. Fundamenteel medischbiologisch onderzoek kan aangrijpingspunten opleveren voor de ontwikkeling van nieuwe behandelingsmogelijkheden. Een mogelijk medicijn is alleen succesvol als het een verbetering of stabilisatie laat zien ten opzichte van het natuurlijke beloop. Het 
vastleggen van het natuurlijke beloop in een registratiesysteem is een belangrijke randvoorwaarde voor medicijnontwikkeling. Bovendien moeten we, om te kunnen beoordelen of een behandeling effect heeft, beschikken over goede meetinstrumenten om verbetering of stabilisatie te meten. Hier kom ik later op terug. 


\section{Dunnevezelneuropathie}

Een tweede speerpunt is dunnevezelneuropathie: een aandoening van de zenuwen waarbij twee subtypes zenuwvezels zijn aangedaan. Zenuwvezels kunt $\mathrm{u}$ zich voorstellen als de koperdraden in elektriciteitssnoer. Bij dunnevezelneuropathie gaat het dan om de vezels zonder isolatielaagje, de zogenaamde C-vezels, en de vezels met een heel dun isolatielaagje, de $A \delta$-vezels. Deze vezels verzorgen het gevoel voor warmte en koude, en reageren op pijn door prikkels van buiten, bijvoorbeeld wanneer je, als niet zo handige klusser, met een hamer op je duim slaat. Ook zijn deze vezels een onderdeel van het autonome zenuwstelsel, dat die functies regelt waar we zelf meestal geen controle over hebben, zoals hartslag, bloeddruk en darmfuncties.

Dunnevezelneuropathie leidt tot vaak ernstige pijnklachten, brandend, prikkelend en soms schietend van karakter.

Daarbij kunnen ook klachten optreden van het autonome zenuwstelsel, zoals droge ogen en droge mond, moeite met scherp stellen van de ogen, meer of juist veel minder transpireren, problemen met plassen, maagdarmklachten, opvliegers, duizeligheid bij overeind komen en hartkloppingen.

Het hebben van chronische pijn, vaak ernstig van aard, heeft een enorme impact op de kwaliteit van leven van een patiënt, vergelijkbaar met bijvoorbeeld het krijgen van een hartinfarct. Het heeft gevolgen voor de vooruitzichten en op de mogelijkheden die iemand heeft. Depressieve klachten en angst komen dan ook veel vaker voor bij deze patiënten dan in de algemene bevolking.

De klachten ontregelen het hele leven: de patiënt met dunnevezelneuropathie staat continu onder vuur, zoals dit plaatje laat zien. Het is een schilderij dat werd gemaakt door een kunstenaar die de woorden en voeten van zijn vrouw vanuit frustratie weergaf.

Ook blijkt de ziekte veel minder zeldzaam dan werd gedacht: minstens 53 van de 100.000 mensen heeft dunnevezelneuropathie, en dat is waarschijnlijk nog een onderschatting van het werkelijke aantal.

Dunnevezelneuropathie werd pas een erkende entiteit toen het mogelijk werd het aantal dunne zenuwvezels in een huidbiopt te bepalen. Een stansbiopt van $3 \mathrm{~mm}$ wordt circa $10 \mathrm{~cm}$ boven de enkel afgenomen, waarna het biopt wordt gekleurd met antilichamen tegen een bepaald eiwit in de zenuw, het PGP 9.5.

Vervolgens kan het aantal dunne zenuwvezels dat de basaalmembraan, de grens tussen opperhuid en lederhuid, passeert onder een lichtmicroscoop worden geteld. 


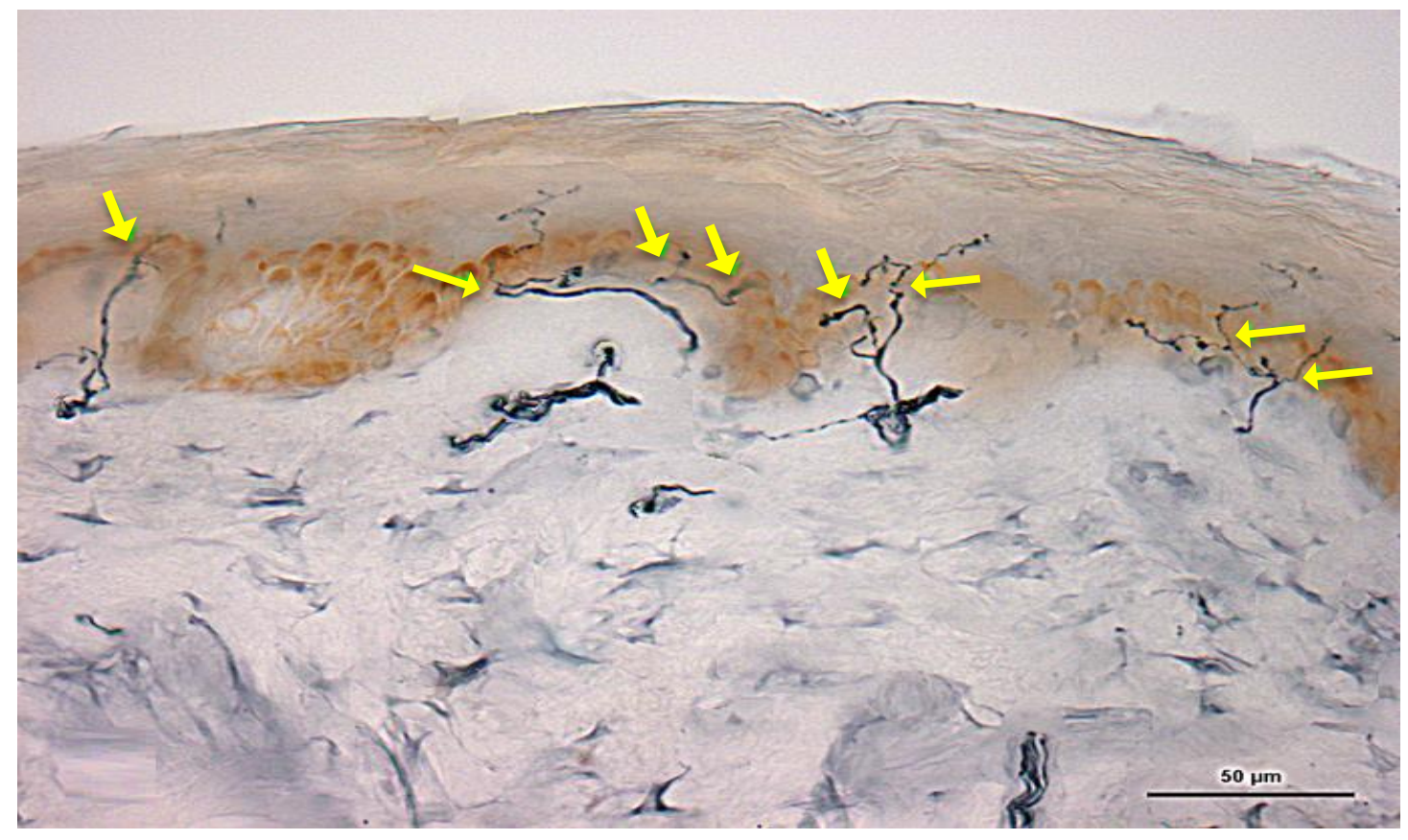

$\mathrm{U}$ ziet die hier aangegeven met de gele pijlen. Hoewel de techniek al eind jaren 90 werd beschreven, duurde het nog geruime tijd voor er goede normaalwaarden beschikbaar waren. Ingemar Merkies stond aan de basis van ons huidbiopten lab, en aan het verzamelen van de normaalwaarden die inmiddels wereldwijd als standaard gebruikt worden.

Het monnikenwerk, namelijk het kleuren en tellen van alle biopten, werd gedaan door onze huidbioptenkoningin Mayienne Bakkers. Deze normaalwaarden hebben het huidbiopt tot een standaardtest gemaakt voor het stellen van de diagnose dunnevezelneuropathie.

Daarnaast wordt ook vaak gebruik gemaakt van het temperatuurdrempelonderzoek en van een aantal andere testen waarvan de waarde nog bewezen moeten worden.

Maar na het stellen van de diagnose zijn we er niet. Dunnevezelneuropathie is eerder aan aantal symptomen bij elkaar dan een aandoening op zich. Vele verschillende ziektes kunnen dunnevezelneuropathie veroorzaken. De meest voorkomende is suikerziekte. Maar ook bijvoorbeeld overmatig alcoholgebruik, stofwisselingsziekten, aandoeningen van het afweersysteem en erfelijke aandoeningen. De lijst is heel lang. Bij een deel van de patiënten, ongeveer een derde, wordt geen onderliggende oorzaak gevonden.

Eigenlijk is het vreemd: waarom zijn er zoveel verschillende aandoeningen die allemaal dezelfde klachten geven? Of, zoals onze klinimetrist formuleerde: 'dit is niet logisch, om niet te zeggen onzinnig. Zou er niet een common pathway kunnen zijn, een gemeenschappelijk mechanisme, voor meerdere aandoeningen.

Uitgebreide literatuurstudie leidde naar de natriumkanalen. Want pijn ontstaat door 
een signaal, een "stroom", genaamd actiepotentiaal, in een zenuw, en stroomspanningsafhankelijke natriumkanalen spelen een belangrijke rol bij het ontstaan van deze actiepotentialen. Er zijn verschillende vormen van deze natriumkanalen en in de dunne zenuwvezels komen vooral de spanningsafhankelijke natriumkanalen Nav1.7, Nav1.8 en Nav1.9 voor.

Bovendien waren er drie aandoeningen buiten de neurologie beschreven, gerelateerd aan pijn, waarbij er een afwijking is in deze natriumkanalen.

Wanneer het Nav1.7 kanaal niet functioneert, leidt dit tot aangeboren ongevoeligheid voor pijn. Denk bijvoorbeeld aan fakirs.

Maar er zijn ook aandoeningen waarbij er een toename is van de werking van het Nav1.7.

Erythermalgie geeft aanvallen van roodverkleurde handen en voeten en zeer hevige pijn. Bij het paroxysmale-extreme-pijnsyndroom treedt aanvalsgewijs zeer hevige pijn op, vooral in het gelaat en in het bekkengebied.

Met name het klinische beeld van primaire erythermalgie vertoont enkele overeenkomsten met dunnevezelneuropathie. Bij beiden is er vaak sprake van een brandende distale pijn. Bij erythermalgie is er een rode verkleuring van de extremiteiten die optreedt of toeneemt bij warmte en bij inspanning. Deze verkleuring wordt bij een deel van de patiënten met dunnevezelneuropathie ook gezien.

Inderdaad bleek bij een deel van de patiënten sprake van een verandering in het natriumkanaal Nav1.7. Op zich was dit een aardige bevinding, maar was deze verandering ook echt verantwoordelijk voor de klachten van de patiënten. Om dat aan te tonen werden de mutaties vervolgens ingebouwd in gekweekte niercellen en in zenuwcellen, de zogenaamde dorsale ganglioncellen.

Functionele 'patch clamp'- en 'current clamp'-studies, waarbij op celniveau de ionenstroom door een ionkanaal kan worden gemeten, lieten zien dat de mutaties functionele gevolgen hadden voor het natriumkanaal; bij elke mutatie ontstond namelijk overmatig vuren van de dorsale ganglioncellen. De hypothese is daarbij dat dit overmatige vuren leidt tot pijnklachten en autonome disfunctie.

In cellen werd in het laboratorium aangetoond dat er in aanwezigheid van een mutatie inderdaad schade optreedt aan de zenuwen, waarschijnlijk door de verhoogde activiteit van de natriumkanalen.

Het blokkeren van het natriumkanaal met een medicijn blijkt deze schade te voorkomen.

Het overmatig vuren wordt veroorzaakt doordat de kanalen langer dan normaal open blijven staan met als gevolg dat natrium meer dan normaal de cel instroomt. In een poging van de cel dit natrium eruit te pompen, stroomt extra calcium de cel in. En een verhoogd calcium in de cel is schadelijk. Ook het remmen van de instroom van het calcium blijkt in het laboratorium de schade aan de zenuwen te voorkomen met meer uitgroei van de zenuwen. 
Dit betekent dat dit mogelijke aangrijpingspunten zijn voor ontwikkeling van medicijnen.

Vervolgens werden ook veranderingen aangetoond in de andere natriumkanalen, Nav1.8 en Nav1.9. Het aantonen van mutaties als mogelijke oorzaak voor dunnevezelneuropathie is belangrijk: het heeft een verandering gegeven in het denken over dunnevezelneuropathie, het ziektebeeld heeft een duidelijker gezicht gekregen, zoals is beschreven in het proefschrift van Janneke Hoeijmakers. Het biedt nieuwe mogelijkheden voor de ontwikkeling van gerichte behandeling. Ook vinden patiënten het belangrijk om te weten waar hun klachten vandaan komen. Hoewel we in de afgelopen jaren veel hebben bereikt liggen ook op dit gebied nog veel vragen open.

Volgens internationale criteria kan de diagnose dunnevezelneuropathie worden gesteld op basis van het klinische beeld in combinatie met een afwijkend huidbiopt en/of een afwijkend temperatuurdrempelonderzoek. Het huidbiopt is een objectieve test, met goede normaalwaarden, maar de sensitiviteit is niet optimaal, wat betekent dat niet iedere patiënt met dunnevezelneuropathie een verminderd aantal zenuwvezels heeft. Het temperatuurdrempelonderzoek aan de andere kant is niet objectief. De uitslag is afhankelijk van de concentratie en medewerking van de patiënt. Bovendien is de test niet specifiek, wat wil zeggen dat een afwijkende test kan voorkomen bij iemand die een andere aandoening heeft dan dunnevezelneuropathie. $\mathrm{Er}$ is dus behoefte aan aanvullende testen die in de dagelijkse praktijk bruikbaar zijn, en met een acceptabele sensitiviteit en specificiteit. Verder onderzoek naar dergelijke testen wordt momenteel uitgevoerd.

Ik heb $\mathrm{u}$ al laten zien dat er vele verschillende aandoeningen zijn die dunnevezelneuropathie kunnen geven, en dat we van daaruit op de natriumkanalen terecht zijn gekomen. Eén van de meest voorkomende oorzaken voor dunnevezelneuropathie is suikerziekte. Maar als we het nu eens omdraaien: van alle patiënten met suikerziekte ontwikkelt ongeveer de helft een neuropathie. Ongeveer de helft daarvan krijgt een pijnlijke neuropathie, dus ongeveer een kwart van het totaal aantal patiënten.

Als diabetes een regelrechte oorzaak zou zijn voor het ontwikkelen van een pijnlijke neuropathie, waarom krijgt dan maar een deel van de mensen last van deze complicatie? Ook dat is toch niet echt logisch.

Van de patiënten met dunnevezelneuropathie en een mutatie in het Nav1.7 bleken een aantal patiënten suikerziekte te hebben ontwikkeld, soms vele jaren na het ontstaan van de klachten van dunnevezelneuropathie.

Janneke Hoeijmakers heeft dit uitgezocht: het Nav1.7 blijkt ook voor te komen in de beta-cellen van de pancreas, die zorgen voor het vrijkomen van insuline. En misschien is dus bij een deel van de patiënten zowel de diabetes als de 
dunnevezelneuropathie het gevolg van een mutatie in het Nav1.7.

Bovendien kan het ook zo zijn dat veranderingen in de natriumkanalen mensen met diabetes gevoeliger maken voor het ontstaan van een dunnevezelneuropathie. En mogelijk spelen ook andere genetische factoren een rol. Dit alles wordt verder onderzocht in de Propane studie, een internationale studie naar de rol van erfelijke factoren bij het ontstaan van pijnlijke neuropathieën.

De behandeling van dunnevezelneuropathie is gericht op het verminderen van de pijnklachten. Helaas is deze behandeling vaak teleurstellend, omdat de middelen die worden gebruikt niet voldoende effect hebben, of teveel bijwerkingen geven.

De ontdekking dat natriumkanalen een rol spelen, biedt nieuwe aangrijpingspunten voor een betere behandeling. Er wordt door verschillende bedrijven gewerkt aan de ontwikkeling van selectieve natriumkanaalblokkers. In eerste instantie zullen deze worden getest bij patiënten met een mutatie in het Nav1.7. Maar omdat het Nav1.7 een centrale rol speelt bij de ontwikkeling van pijn, zou een dergelijk middel mogelijk ook werkzaam kunnen zijn bij patiënten zonder een mutatie.

Naast behandeling met medicatie zijn ook andere behandelingsstrategieën van belang. Is er, zoals bij diabetische pijnlijke neuropathie, een plaats voor behandeling met ruggenmergstimulatie? Een vraag die momenteel wordt onderzocht binnen het pijnkenniscentrum onder leiding van Maarten van Kleef.

Hoe moeten patiënten met dunnevezelneuropathie verder worden behandeld? Is oefenen met zogenaamde graded exposure goed? Is er een plaats voor mindfulness? Welke patiënten hebben baat bij ondersteuning door een psycholoog of psychiater? Vragen die verder zullen worden onderzocht in samenwerking met de afdeling revalidatie en met de afdeling psychiatrie.

En hoe onderzoeken we of we het goed doen, dus of onze interventies ook leiden tot een verbetering bij de patiënten. De patiënten zijn immers de $2^{\mathrm{e}}$ 'waarom', de reden dat we dit allemaal doen. Om te onderzoeken of onze behandelingen effect hebben, moeten we gebruik maken van goede uitkomstmaten. 


\section{Klinimetrie}

En dat brengt ons bij klinimetrie. Klinimetrie is de leer van het meten van klinische veranderingen bij patiënten met een chronische ziekte of ziekten met chronische consequenties. Eigenlijk bestaat ons hele leven uit klinimetrie - alles wat we doen heeft met metingen te maken: de hoeveelheid pindakaas op ons brood, hoe snel we rijden, hoe ver we hebben hardgelopen, al onze metingen bij een patiënt: alles is meetkunde. In wetenschappelijk onderzoeken, maar ook in de dagelijkse praktijk worden allerlei testen en vragenlijsten gebruikt om de ernst van de verschijnselen van ziekten vast te leggen, om het verloop van een ziekte te volgen en om het effect van een behandeling te kunnen meten. Deze testen en lijsten worden uitkomstmaten genoemd. Hierbij wordt gekeken naar stoornissen aan het lichaam, zoals bijvoorbeeld een verminderd gevoel of spierzwakte, maar ook naar het dagelijks en sociaal functioneren en naar de kwaliteit van leven. In feite vormt klinimetrie de basis, het fundament, voor ieder wetenschappelijk onderzoek. Maar ook voor het bepalen van het natuurlijk beloop. Men kan geen huis bouwen zonder een goed fundament, zelfs een kind dat met Lego speelt weet dat. Helaas doen wij dokters vaak het omgekeerde: we beginnen een onderzoek, om er vervolgens achter te komen dat we niet weten hoe we moeten meten of het beter gaat met de patiënt.

Sommige uitkomsten zijn zo duidelijk dat er geen studie of uitkomstmaat nodig is. Niemand met gezond verstand twijfelt aan de uitkomst wanneer je zonder een parachute uit een vliegtuig springt. Maar dergelijke situaties zijn in de dagelijkse praktijk zeldzaam, en dan hebben we wel uitkomstmaten nodig. Wanneer nietoptimaal opgestelde (doorgaans ordinale) uitkomstmaten als primaire uitkomstmaat bij een onderzoek worden gebruikt, kunnen de resultaten van zo'n studie valsnegatief of vals-positief zijn. Het uiteindelijke effect is dat patiënten benadeeld worden door het niet voorschrijven van een behandeling die eigenlijk wel werkt, maar niet opgemerkt is door de gebruikte uitkomstmaat, of omgekeerd: juist wel behandeld worden, terwijl een middel niet werkt (met kosten en mogelijke risico's van de behandeling). Beide situaties zijn vanzelfsprekend zeer onwenselijk, maar zijn in de afgelopen jaren helaas meerdere keren voorgekomen.

Bovendien worden er, zowel binnen de neuromusculaire aandoeningen, als binnen de gehele geneeskunde, een zeer grote hoeveelheid verschillende soorten uitkomstmaten gebruikt, wat het bijna onmogelijk maakt resultaten van trials te vergelijken.

Wanneer van iemand de lengte wordt gemeten, kan een meetlat worden gebruikt, en wordt de lengte weergegeven in centimeters (of in het Engels in feet). Maar wanneer geen meetlat met centimeters beschikbaar is, moet een ander meetinstrument worden gekozen. 


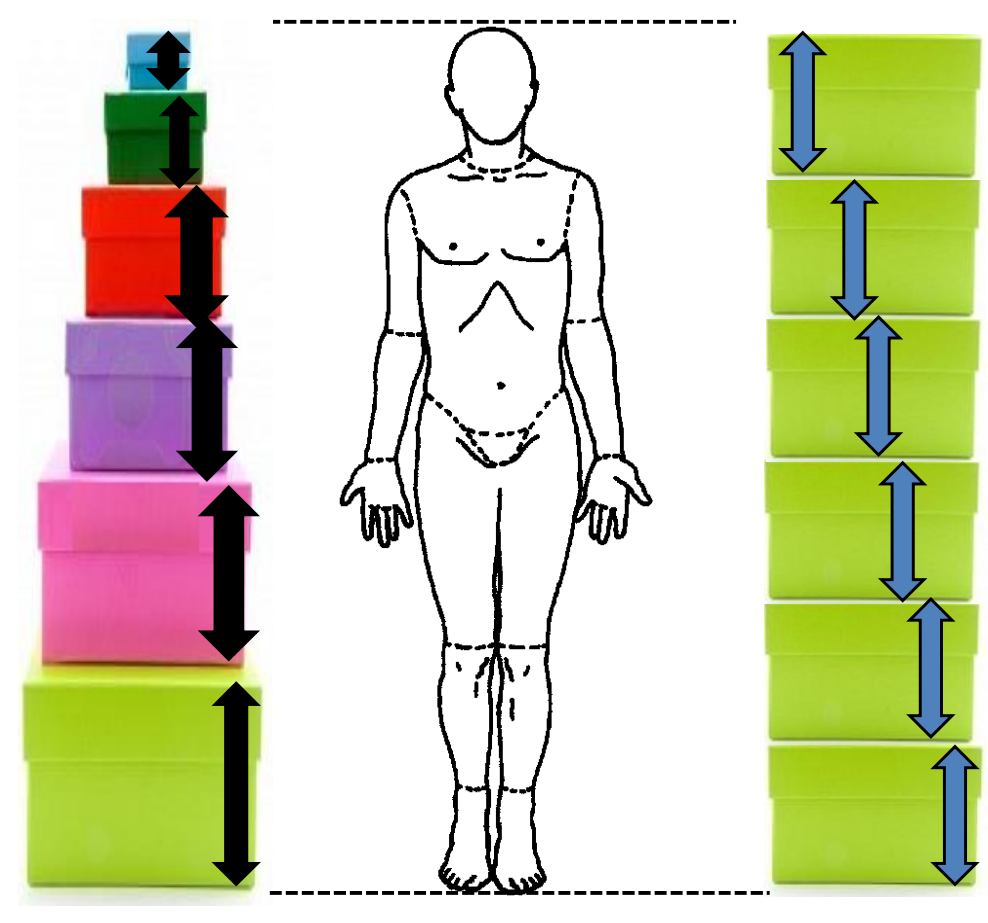

Wanneer ik u vraag welke dozen uw voorkeur hebben om de lengte te meten, dan kiezen de meeste mensen voor de groene dozen. Het argument is dat die allemaal even hoog zijn. We weten dan dat iemand met een lengte van 5 dozen 5/6 meet van de lengte van iemand met 6 dozen, terwijl dat in het linker plaatje niet duidelijk is. Met andere woorden: aan de linkerkant draagt niet iedere doos evenveel bij aan het meten van de lengte. Helaas is de situatie aan de linkerkant een afspiegeling van de dagelijkse praktijk, ook binnen het wetenschappelijk onderzoek. Voor veel dingen die wij van een patiënt willen weten, bestaat geen meetlat, en bestaat het meetinstrument uit items of vragen die niet allemaal dezelfde waarde hebben. Denk bijvoorbeeld aan kwaliteiten zoals vermoeidheid, pijn of depressie. Vaak wordt in dergelijke gevallen gebruik gemaakt van een vragenlijst.

Er bestaat een wiskundig model dat het mogelijk maakt uitkomstmaten te creëren die deze problemen ondervangen: het Rasch model.

Het Rasch-model gaat er vanuit dat de kans dat een persoon met minder beperkingen een bepaalde activiteit kan uitvoeren, groter is dan voor een persoon met meer beperkingen.

De antwoorden van de patiënten worden gebruikt om de mate van beperking en de moeilijkheid van de activiteit of opdracht te bepalen. Vervolgens kunnen de personen naar mate van beperking geordend worden op een schaal, een liniaal, met een vaste eenheid, zoals bij het meten van de lengte. Ook kunnen de activiteiten of 
opdrachten naar moeilijkheid worden geordend op dezelfde liniaal.

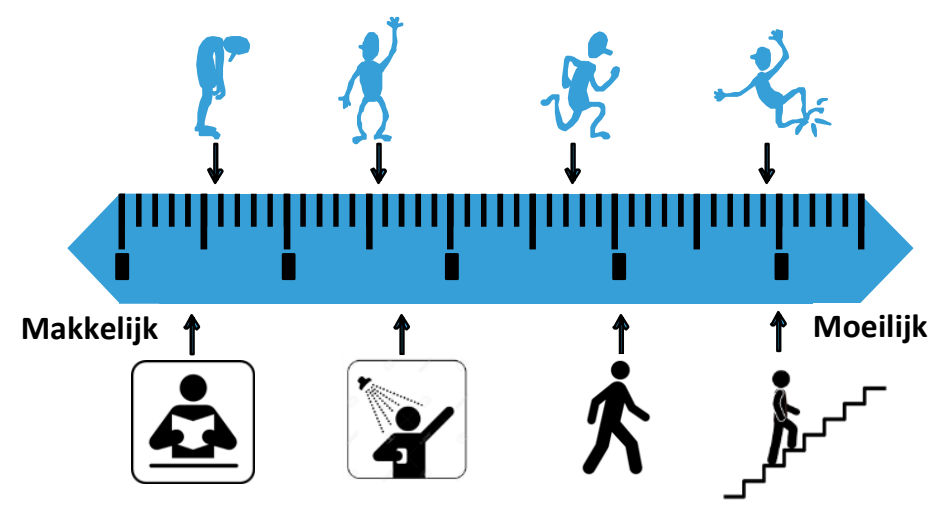

Zo'n intervalsmaat is verreweg het meest optimaal om het natuurlijke beloop te onderzoeken van patiënten met chronische aandoeningen, en als uitkomstmaat te gebruiken bij interventionele studies. Dit klinkt heel ingewikkeld, maar het is slechts een methode, een techniek, die wordt gebruikt om een uitkomstmaat te ontwikkelen die aan internationale klinimetrische eisen voldoet. Het gebruik van deze uitkomstmaat is hetzelfde, dus even eenvoudig als bijvoorbeeld de vragenlijst.

Waar dagelijkse activiteiten zoals het opstaan, tanden poetsen, douchen, lopen, en werken niet primair afhankelijk zijn van het wel of niet gezond zijn, of van het hebben van een onderliggende chronische ziekte, zoals bijvoorbeeld myotone dystrofie, is de betekenis (de zogenaamde weging) van een taak wel afhankelijk van de onderliggende ziekte, en van de patiënt.

Voor ontstekingsachtige neuropathieën, zoals het Guillain-Barré syndroom, CIDP en $M M N$, en voor myotone dystrofie en dunnevezelneuropathie heeft onze groep ziekte-specifieke functionele uitkomstmaten ontwikkeld, de zogenaamde "Raschbuilt overall disablity scales", oftewel de RODS-familie van schalen. Deze lijsten zijn ziekte-specifiek, dat wil zeggen dat niet alle items hetzelfde zijn, en dat de weging van overeenkomstige items per ziekte verschillend kan zijn. Door echter overeenkomstige items met elkaar te verbinden, is het wel mogelijk om al deze aandoeningen op één grotere liniaal te zetten.

Sommigen vragen zich af of zo'n RODS-schaal, die door de patiënt zelf wordt ingevuld, wel betrouwbaar is. We varen immers op het oordeel van de patiënt, en 'meten' niet zelf iets. Het bleek dat de RODS bijvoorbeeld bij patiënten met GBS en 
CIDP buitengewoon goed correleerde met de knijpkracht, gemeten met een dynamometer. Kortom: de patiënt, mijn $2^{\mathrm{e}}$ waarom, is zeer goed in staat om aan te geven hoe het met hem of haar gaat.

Het zou ideaal zijn om één functionele uitkomstmaat te ontwikkelen voor alle neuromusculaire ziektebeelden, gericht op het dagelijkse en sociaal functioneren. Deze uitkomstmaat moet ziekte-specifiek zijn, waarbij de weging van de dagelijkse activiteiten per ziektebeeld anders kan zijn. De uitkomstmaat kan op individueel niveau gebruikt worden om "patiënt-specifieke" veranderingen in het klinische beeld te monitoren. Op groepsniveau kan deze gebruikt worden om bijvoorbeeld scores tussen ziektebeelden met elkaar te vergelijken.

Even een kort uitstapje: ziekenhuizen worden momenteel overstroomd met zogenaamde prestatie-indicatoren. Inmiddels zijn dat er meer dan 2.000. Het gaat dan om indicatoren zoals: hoeveel mensen vallen uit bed, welk percentage van de patiënten met een gebroken heup wordt pas na 24 uur geopereerd, hoe lang is de gemiddelde door-to-needle tijd van een patiënt met een herseninfarct, enzovoort. Deze getallen zeggen iets over de processen, maar nog steeds niets over de werkelijke kwaliteit van de zorg. Voor de patiënt is uiteindelijk het meest belangrijk hoe hij in functioneel opzicht herstelt, met andere woorden: "hoe gaat het met de patiënt", bij binnenkomst in een ziekenhuis, en bijvoorbeeld na een behandeling, of na verloop van tijd. Dat vergt één functionele uitkomstmaat op intervalsniveau.

In een ideale situatie creëren we niet alleen een neuromusculaire RODS, maar ook een neurologische functionele uitkomstmaat voor de neurologie. Dit is te bereiken door op soortgelijke manier een ziekte-specifieke functionele index te creëren voor verschillende aandoeningen binnen de neurologie, zoals bijvoorbeeld een hernia, carpaal tunnelsyndroom, herseninfarct, de ziekte van Parkinson en multipele sclerose. Een dergelijke functionele maat kan gebruikt worden om het natuurlijk beloop te meten, op individueel niveau, op groepsniveau, tussen groepen van ziektebeelden, en kan ook gebruikt worden in toekomstige interventionele studies.

Nog idealer is het wanneer we dit niet alleen voor de neurologie doen, maar voor iedere afdeling. Op deze wijze beschik je over een ziekenhuis-brede functionele uitkomstmaat. Dan heb je pas echt de mogelijkheid om te benchmarken.

De grootste uitdaging zit erin dokters en wetenschappers hiervan te overtuigen, hen weer een link te geven naar hun kind-zijn, waardoor zij flexibel kunnen zijn zoals mijn $1^{\mathrm{e}}$ waarom: mijn kinderen. Dan kunnen wij als dokters inzien dat de manier waarop we dingen 70 jaar of langer hebben gedaan, niet de juiste is. Die verandering is geen eenvoudige opdracht. Maar wanneer we willen dat de behandeling van onze patiënten verbetert, is alleen zoeken naar nieuwe geneesmiddelen niet genoeg. Dan 
hebben we ook excellente meetinstrumenten nodig om verbetering te meten. Alleen dan kunnen we excellente zorg bieden.

Voor excellente zorg is natuurlijk nog meer nodig. In een tijd en een omgeving waarin veel verandert in de gezondheidszorg, en waarin kosten verminderd moeten worden, hebben ziekenhuizen er een ingewikkelde opdracht bij gekregen. 


\section{Operational excellence}

Het Maastricht UMC+ is de afgelopen jaren de weg ingeslagen van operational excellence, met de overtuiging om te willen excelleren in de dienstverlening naar onze klanten. Operational excellence is een denkwijze, waarbinnen Lean Six Sigma een verbetermethodiek is. Ook dit klinkt ingewikkeld, maar net als bij de Rasch is het een methode, waar je doorheen moet kijken om te zien wat het einddoel is.

Binnen operational excellence staat de klant centraal, en een UMC heeft nogal wat klanten: de patiënten natuurlijk, maar ook andere afdelingen, de universiteit, studenten, co-assistenten, arts-assistenten in opleiding tot specialist, het ministerie, de verzekeraars, onderzoeksfondsen..... zeker geen eenvoudige opgave dus. Critici zeggen dan ook dat dit traject voor een UMC niet werkt, omdat het geen bedrijf is. En het laat zich ook niet één-op-één vertalen: een universiteitsziekenhuis is niet hetzelfde als Toyota of Medtronic. Maar het doorlopend zoeken naar verbeterpunten, waarbij je juist de werknemers zelf inzet om verbeterpunten te signaleren, verbeterplannen te maken en uit te voeren, levert grote voordelen op. Voor de organisatie, die verbetert, voor de werknemers, die zelf aan het roer staan en invloed hebben op de manier waarop ze hun werk doen, en voor de patiënten, omdat de zorg verandert door continue verbetering.

Met operational excellence wordt optimaal gebruik gemaakt van de kennis van de mensen op de werkplek zelf, die weten waar ze tegenaan lopen, wat wel kan en wat niet. Het inzetten op operational excellence is niet vanzelfsprekend, en evenmin een gemakkelijke oplossing. Het betekent een enorme investering, onder andere in tijd, scholing, training en in coachend leiderschap. Het eigen maken van deze werkwijze is een lang traject. Maar wanneer je als organisatie wilt overleven en zelfs wilt excelleren in een voortdurend veranderende omgeving, zul je je moeten onderscheiden. Onderscheiden in kwaliteit en in dienstverlening. Maar ook onderscheiden voor je werknemers. Daarbij moet je heel goed weten wie je klanten zijn en wat voor hen van waarde is.

Want als je dat niet weet, hoe kun je dan werken aan veranderingen tot verbetering. Welke kant moet je op, wat is goed en wat is fout?

Bepalen van richting voor verandering en verbetering: hierdoor kenschetst zich onze grootste uitdaging voor de komende jaren. Binnen de spierziekten, binnen het onderzoek en de patiëntenzorg, maar ook binnen de gehele gezondheidszorg veranderen de tijden. Er is een grens aan wat wij kunnen betalen. Wij zullen dus mee moeten veranderen: we zullen moeten definiëren wat waarde heeft in de gezondheidszorg. En we moeten weten hoe we die waarde of toevoeging van waarde meten, en het liefste met één maat. Alleen dan zijn we in staat richting te bepalen en zelf richting te geven aan verandering. Als we dat niet doen, zijn we als een losgeslagen schip op zee, en overgeleverd aan de waan van de dag. Wij, de mensen werkzaam in de gezondheidszorg, zullen zelf richting moeten geven, en wel 
samen met onze patiënten. Alleen dan kunnen we, wanneer tijden veranderen, ook zelf veranderen in de goede richting. 


\section{Dankwoord}

$U$ begrijpt dat ik hier wel sta, maar dat ik hier sta mede dankzij en mede namens vele andere mensen, die ik graag wil bedanken. Omwille van de tijd houd ik het beperkt, maar wees ervan overtuigd dat ik iedereen met wie ik werk een warm hart toedraag, en blij ben dat ik in het Maastricht UMC kan en mag werken. Zonder mijn vele collegae artsen, verpleegkundigen, paramedici en de patiënten zou ik dit werk niet kunnen doen, of met veel minder plezier doen. Een aantal mensen wil ik met naam noemen. De leden van de Raad van Bestuur Guy Peeters, Marja van Dieijen, Lou Brans Brabant, Albert Scherpbier en Frits van Merode: ieder van jullie heeft mij gesteund en gestimuleerd mijzelf verder te ontwikkelen. leder op een ander moment en op andere wijze, maar allen waardevol. Jullie vormen een Raad van Bestuur waar menig UMC jaloers op kan zijn.

Het onderzoeksinstituut Mental Health \& Neuroscience, met als directeur Harry Steinbusch, verdient mijn dank voor hun ondersteuning bij ons wetenschappelijk onderzoek.

Mijn opleider en promotor Jaap Troost, die mij vanaf dag één van mijn coschap Neurologie in het Medisch Spectrum Twente stimuleerde, en eindeloos veel vertrouwen gaf. Mede dankzij jou ging ik neurologie doen, kwam ik terecht in Maastricht, deed ik promotieonderzoek, belandde ik in de spierziekten, en kreeg ik een vaste aanstelling. Met oprechte belangstelling volg je nog steeds wat er met mij en met onze vakgroep gebeurt, en zonder jou had ik hier nu niet gestaan.

Chris Höweler stimuleerde mij in mijn eerste stappen binnen het neuromusculaire veld. Hij was degene die mij zei: myotone dystrofie, dat is een ziekte waar je van moet leren houden. Hoe raar vond ik dat toen, maar hoe gelijk heeft hij gehad. Nadien heb ik heel veel geleerd van Christine de Die, die onder Chris Höweler promotieonderzoek heeft gedaan naar myotone dystrofie, en met wie ik nog steeds met heel veel plezier de neurogenetica poli doe.

Robert van Oostenbrugge, hoofd van de afdeling neurologie. Samen hebben we de opleiding gedaan, samen hebben we heel wat doorstaan, in goede en in kwade dagen en we weten wat we aan elkaar hebben. Ik heb veel bewondering voor de wijze waarop je de afdeling door zwaar weer hebt geloodst, en ben dankbaar voor je hulp en steun bij de verdere ontwikkeling van ons spierziektencentrum. Mijn andere collega neurologen, zowel van de volwassen- als de kinderneurologie wil ik bedanken. We hebben een fijne en collegiale groep, waarin we op elkaar zijn aangewezen. Het feit dat iedereen altijd bereid is in te springen of iets voor elkaar over te nemen, ondanks de hoge werkdruk, is een groot goed, en ik hoop dat we dat gezamenlijk zo kunnen voortzetten.

Het secretariaat neurologie wil ik danken voor de doorlopende ondersteuning, en met name Miranda, Maddy en Vivian. En hoewel al lang afwezig door ziekte, wil ik ook Marian niet vergeten, die zoveel heeft gedaan voor de planning van de opnames van patiënten met myotone dystrofie. 
Charlotte van Hoegee regelt alles voor de myotone dystrofie poli's en coördineert samen met Edith Peeters de dunnevezelneuropathie; zonder jullie zouden we niet zoveel service kunnen bieden. De afdeling klinische neurofysiologie speelt voor een neuromusculaire afdeling een belangrijke rol in de diagnostiek, en ik wil zowel de stafleden als de laboranten danken voor hun hulp en flexibiliteit. De afdeling pathologie, en met name Ilse Driesmans, Aline Kosten en Benoit Frère, die eindeloos biopten kleuren en tellen, altijd bereid zijn met ons mee te denken en gasten van elders te scholen wil ik ook danken.

Patiënten met spierziekten hebben naast spierzwakte vaak ook andere problemen, en we werken dan ook, zowel voor patiëntenzorg als onderzoek. samen met vele andere afdelingen en medisch specialisten, die ik eveneens wil danken: de leden van het ALS team, van het myotone dystrofie team, en allen die betrokken zijn bij de dunnevezelneuropathie.

Collega neurologen in het land, collega's binnen Spierziekten Centrum Nederland, Spierziekten Nederland, en het Prinses Beatrix Spierfonds dank ik voor de jarenlange prettige samenwerking.

De afgelopen jaren promoveerden Mieke Hermans, Jeroen Trip, Elske Hoitsma, Janneke Hoeijmakers, Mayienne Bakkers, Sonja van Nes en Els Vanhoutte. Het werk wordt voortgezet door Bianca de Greef, Maurice Sopacua, Brigitte Brouwer, Tim Draak en Marielle Pruppers. Daarnaast hebben we doorlopend de onmisbare ondersteuning van Carla Gorissen, Margot Geerts en nogmaals Janneke, die een vast baken is, en met oneindige energie betrokken is bij al het onderzoek. Janneke, ik ben erg blij dat jij in Maastricht kan blijven, en verheug me op onze doorgaande samenwerking.

Binnen de Propane studie zijn daarnaast ook vele anderen van buiten de neurologie van onschatbare waarde: Monique Gerrits, Rowida Al Momani, Bert Smeets, Jo Vanoevelen, Patrick Lindsey, Radek Sclarzcyk, Markos Xenakis, Ivo Eijkenboom, Ronald Westra, en onze internationale partners Stephen Waxman, Sulayman Dib Hajj en hun medewerkers van Yale University, en Giuseppe Lauria van Carlo Besta uit Milaan.

Ons onderzoek had nooit gestaan waar het nu staat zonder Ingemar Merkies. Ingemar wil het liefst niet in de schijnwerpers staan, hij wil dus ook het liefst niet dat ik vertel wat hij doet, maar vandaag heeft hij een klein beetje pech. Ingemar, immens bedankt dat ik vandaag hier mag staan, zonder jouw steun, creatieve geest, statistische ondersteuning en richting zou het mij niet gelukt zijn.

Fulltime werkzaam als neuroloog in het Spaarne Ziekenhuis, met tevens een 0aanstelling in Maastricht, en een tomeloze hoeveelheid energie blijf je iedereen constant duwen, duwen om na te denken, om te veranderen en te verbeteren. Ingemar zegt vaak niet veel, maar observeert goed en ziet alles. Zijn motto is dat zaken simpel moeten zijn, logisch en ordelijk: u kunt begrijpen dat hij het soms heel zwaar heeft met zoveel vrouwen om zich heen. Samen hebben we de afgelopen 10 
jaar de groep opgebouwd zoals die nu is, en waarop we beiden trots zijn. Ik hoop dat wij nog vele jaren blijven samenwerken, ook al zit je binnenkort op jouw geliefde eiland.

Last but not least: mijn moeder. Zij was en is mijn voorbeeld. Van haar leerde ik dat je prima kunt werken als vrouw zonder dat je kinderen tekort komen. Van haar leerde ik ook dat je als vrouw altijd op je eigen benen moet kunnen staan; een les waar ik haar veel later in mijn leven heel dankbaar voor ben geweest. Mijn moeder zei nooit veel, maar ik wist altijd wat ze dacht, wat haar goedkeuring kon wegdragen en wat niet, en met haar rust en haar aanwezigheid wist ze me altijd in de goede richting te duwen. Een betere moeder had ik me niet kunnen wensen, en ik ben dan ook een gelukkig mens dat ze sinds 2 jaar zo dichtbij ons woont.

Thomas, David en Casper: ik zei het al aan het begin: jullie zijn mijn 1e waarom. Het belangrijkste in mijn leven. Jullie zijn broers, en toch alle drie zo verschillend. Op ieder van jullie ben ik ongelofelijk trots. Jullie hebben alles in je om te bereiken wat je wilt bereiken. Als je gelooft in wat je doet is geen berg te hoog, en geen weg te lang, en dan komt een keer dat moment: 'op de weg die ik ga, zal ik op een dag stilstaan, verbaasd te zien hoe ver ik ben gekomen'....

Ik heb gezegd. 